\section{MOTION EVENT CONSTRUCTIONS IN SWEDISH, FRENCH AND THAI: THREE DIFFERENT LANGUAGE TYPES?}

\author{
Jordan Zlatev ${ }^{1}$ \\ Caroline David ${ }^{2}$
}

\begin{abstract}
Talmy's influential typology of verbframed/ satellite-framed languages has recently been shown to be insufficient (Strömquist and Verhoeven 2003), in particular with respect of serial-verb languages (Zlatev and Yangklang 2004; Slobin 2003). In this paper, we compare motion event constructions in three languages, where two are clear representatives of Talmy's two types: French and Swedish, and the third is a serial-verb language, Thai. As expected, Thai turns out to resemble French in some respects, Swedish in others but also to possess structural (i.e. syntactic and semantic) characteristics which distinguish it from the two Talmian types. This reinforces, but also clarifies, previous proposals for regarding serialverb languages as belonging to a third "equipollent" type.
\end{abstract}

\footnotetext{
${ }^{1}$ Ph.D., Research Fellow, Department of Linguistics, Lund University, Helgonabacken 12, 22362 Lund, Sweden ${ }^{2} \mathrm{Ph} . \mathrm{D}$., Department of English, University of Poitiers, France
}

\section{Introduction}

From a cognitive-functional point of view grammar can be regarded as a conventional system of interrelated form-meaning mappings, usually referred to as grammatical constructions (Langacker 1987; Goldberg 1995; Croft 2001). It is worth emphasizing that from this perspective a grammatical construction is never just a matter of "syntax", but always a pairing of form and meaning, the first representing (signifying) the latter. In line with this general approach, the major concept of this article can be defined as follows:

\begin{abstract}
A Motion Event Construction (MEC) is a universal linguistic construction consisting of one or more verb phrases and optionally one or more adnominal phrases, which represents the change of location of a trajector according to linguistically specified frames of reference.
\end{abstract}

The emphasized terms in the definition need clarification. MECs are universal since all languages have the lexical category verb (Givón 2001) and within it, a sub-type expressing motion and the means to predicate this motion of a trajector - the focused moving entity. In its simplest form this can be seen in the English sentence He entered. Such motion events are highly salient, both experientially and culturally, and hence it is unsurprising that all languages have "evolved" means to represent them. But some care needs to be paid in defining the notion motion event. First, we must exclude from the definition cases of socalled "self-contained" or locative motion where "an object keeps its same 
basic, or 'average' location", distinguishing this from "translational", or what we prefer to call translocative motion where "an object's basic location shifts from one point to another in space" (Talmy 2000a: 35). The difference between locative and translocative motion is essential: the first represents an activity which takes place at a certain location, as in He ran on the treadmill, while the second represents an event in which the location of the trajector necessarily changes, as in He ran to the house. ${ }^{3}$ Only the second is to be regarded a "motion event", in accordance with the usage of the term in the literature (e.g. Strömquist and Verhoeven 2004).

In order to characterize motion events, minimally some fixed point is necessary and extensive cross-linguistic research has shown that languages use three different reference frames (Levinson 1996, 2003; Pedersen et al. 1998; Zlatev 1997, in press):

Viewpoint-centered: The translocation of the trajector is defined in relation a subjective viewpoint which can be that of the deictic center, as in Put your coat over there, but need not be, as in The church is to the right of the monument, looking from the steps of the palace.

\footnotetext{
${ }^{3}$ As these examples show, the same verb, in this case run, can be involved in the representation of both kinds of situations, and that is why it is necessary to consider the whole sentence, and sometimes the discourse context in order to decide whether the motion involved is locative or transloca tive (Zlatev and Yangklang 2004).
}

Geocentric: The translocation of the trajector is defined in relation to a system of stable external reference points, as in The bird flew upwards.

Object-centered: The translocation of the trajector is defined in relation to a landmark entity, as in The bird flew into the room.

Third, we need to distinguish between two major types of MECs: intransitive, in which the grammatical subject of the sentence expresses the trajectory as in (1a) and transitive ones, in which an agent causes the motion of the trajector coded by the grammatical object (1b).

(1)

a. The ball goes into the goal.

b. He kicked the ball into the goal.

Finally, we should note that even if the basic meaning of MECs is actual physical motion - the kind of motion we will be concerned with in this article - it is well-known that there are close parallels between the syntactic and semantic structure of MECs and constructions expressing change-ofstate events in general, as in (2a) and (2b) (Langacker 1987; Jackendoff 1990; Talmy 2000b), sometimes interpreted in terms of conceptual metaphor (Lakoff and Johnson 1999). Thus MECs are a central part of the grammar (i.e. syntax and semantics) in all of the world's languages.

(2)

a. The prices are going up.

b. The crisis pushed the employee into resignation. 
The main question to be addressed in this article is: Into what major types can languages be divided depending on their way of coding MECs? The conclusive answer to this question was considered to be provided by the influential binary typology of Talmy (1991, 2000). According to this typology, all languages can be divided in two groups, depending on which form-class preferably expresses the category Path of motion, or more generally "the core schema" framed languages where this is done by the verb-root, or satellite-framed languages where this is done by a verbprefix, verb-particle, or some other kind of element in close association ("sister relation") to the verb-root. As summarized by Talmy:

Languages that characteristically map the core schema into the verb will be said to have a framing verb and to be verbframed. Included among such languages are Romance, Semitic, Japanese, Tamil, Polynesian, most Bantu, most Mayan, Nez Perce, and Caddo. On the other hand, languages that characteristically map the core schema onto the satellite will be said to have a framing satellite and to be satelliteframed languages, and included among them are most IndoEuropean minus Romance, Finno-Ugric, Chinese, Ojibwa and Warlpiri. (Talmy 2000b: 222 , emph. original)

${ }^{4}$ Defined in the most general terms as "the association function that sets the figural entity into a particular relationship with the ground entity" (Talmy 2000b: 218).
English is usually considered a satelliteframed language - or 'S-language', following the terminology of Slobin (1996) - but since it has been influenced from other languages and especially Romance is not the clearest possible example. Swedish, on the other hand, is a fairly typical S-language and will serve as our representative for the category in this article. French will be our example of a verb-framed, or ' $V$ language'. (3) and (4) show how the English sentence $I$ swam across the river can be (most naturally) rendered in each:

(3)

Jag simma-de över

1sg swim-PAST across

(flod-en).

river-DEF

(4)

J' ai traversé le fleuve

1sg AUX cross/PAST DEF river

(à la nage)

swimming

In the Swedish sentence (3), the main verb simma 'swim' expresses the Manner of motion, while Path (or the 'core schema') is coded by the verbparticle/preposition över 'across'. The fact that this form is ambiguous concerning the grammatical categories particle and preposition is reflected in the optionality of the landmark-nominal floden 'the river': with it, the form is a preposition, without it, it is rather an appendage or "satellite" to the verb. On the other hand, the coding of the major motion categories is quite different in the French example (4): the main verb traverser 'cross' expresses Path, while Manner is relegated to an optional adverbial phrase, which is most likely omitted in discourse if Manner-of- 
motion is predictable or can be inferred from the context (Khalifa 2002).

But do all of the world's languages follow either the Swedish or the French type in coding motion events? Particularly troublesome are serial-verb languages, found among Niger-Congo, Hmong-Mien, Sino-Tibetan, Tai-Kadai, Mon-Khmer and Austronesian languages (Stahlke 1970; Thepkanjana 1986; Bisang 1995; Durie 1997; Senft 2001). What characterizes these languages, especially in comparison to the more familiar Indo-European languages, is that a single clause representing the same general event can contain two or more verbs with shared nominal arguments. Furthermore it can be argued that at least in some constructions these verbs are of equal status - neither is a modifier of the other(s). Consider the equivalent to (3) and (4) in one serial-verb language, Thai (5a).

a.

chăn wâynáam khâam mêعnáam 1 sg swim cross river

b.

chăn khâam mêعnáam

1sg cross river

c.

*chăn wâynáam mêعnáam

1sg swim river

d.

chăn wâynáam

1sg swim

Here we have not one, but two main verbs - the first one, wâynáam ('swim') lexicalizing Manner and the second khâam ('cross') representing Path. That the second form is a full verb, rather than a "satellite" is shown in (5b). While it is necessary if there is a landmark nominal, as can be seen in the ungrammaticality of $(5 \mathrm{c})$, it is not necessary when this is absent (5d), showing that the first verb could bear the main predication of the sentence. However, this would not be an expression of a motion event, since the motion expressed is not translocative but locative, representing an activity similar to that in the English translation I swam.

Thus it turns out that serial-verb languages like Thai are quite problematic for Talmy's binary typology of MECs, since with their Manner verbs they resemble S-languages and with their Path verbs they resemble Vlanguages. Actual analyses have oscillated from one side to the other. Talmy (1991, 2000b) classified at least two serial-verb languages, Chinese and Lahu, as satellite-framed, while Slobin and Hoiting (1994) proposed that "serialverb languages be reclassified as complex verb-framed types" (ibid: 502) similar to Sign Languages like ASL. More recently, Slobin (2000) suggested that "serial-verb languages like Chinese may represent a third type of lexicalization pattern, lying between Slanguages and V-languages" (ibid: 134), but it remained difficult to explain in which sense they could be said to be "in between".

A strong case for regarding at least two Niger-Congo serial-verb languages, Ewe and Akan, as neither S- nor Vlanguages, but as instantiating a third type, has been made by Essegbey and Ameka (in press), the point being that since they share some features of both 
distinguishes between the "conformation' i.e. Region, and the 'vector' which "comprises the three basic types of arrival, traversal and departure that a Figural schema can execute with respect to the Ground schema" (ibid: 53 ), the latter notion corresponding to our usage of the term Path. Since in this narrow(er) definition Path is always specified in relation to an explicit or implicit landmark, it can also be said to be based on the object-centered Frame of Reference (FoR).

So how is Path expressed in the three languages under analysis? The English sentence $I$ went into the room can be most naturally translated as (6) in Swedish and (7) in French.

Jag gick in

1sg go/PAST in/DIR

(i rum-met)

in $/ \mathrm{L}, \mathrm{C}$ room-DEF

(7)

Je suis entré

1sg AUX enter/PAST

(dans la pièce)

in DEF room

The contrast between "verb-framing" and "satellite-framing" is here even clearer than in the introductory examples (3) and (4), since in both (6) and (7) there are prepositional phrases expressing the Region in which the Path of motion ends: the INTERIOR of some particular room - and both can also be omitted if this Region can be inferred from the context. But the Path ('vector') itself is lexicalized in Swedish by the verb-particle in - which, note, is distinct from the preposition $i$-while in French this is done by the main verb entrer 'enter'. What about Thai then? The simplest ${ }^{5}$ way to render this motion event is given in (8).
(8)

$\begin{array}{lll}\text { chăn } & \text { khâw } & * \text { (hôy) } \\ \text { lsg } & \text { enter room }\end{array}$

This construction is most similar to the French (7), since it is the main verb that expresses Path, but is even simpler in that it does not require a preposition. ${ }^{4}$ However, as shown, it is impossible to omit the landmark nominal - unless a deictic verb pay/maa is added, as will be described in the next section. ${ }^{5}$

Though this can be done if the landmark is clearly obvious from the context as in (ii), as pointed out by Kingarn Thepkanjana (p.c.):

The "reverse" motion event - I went out of the room - is rendered likewise in the three languages, as shown in (9), (10) and (11), save that Thai now also requires a preposition, making the similarity with French even greater, leading some analysts such as Weinold (1995) to classify Thai as a V-language.

${ }^{5}$ Though arguably not the most natural one, which would rather be (i):

(i) chăn khâw pay nay hộ ${ }^{6}$ Save for the lack of morphological markers for tense and definiteness, it is similar to the non-prototypical English sentence with a Romance-borrowed motion verb I entered the room

${ }^{7}$ Though this can be done if the landmark is clearly obvious from the context as in (ii), as pointed out by Kingarn Thepkanjana (p.c.):

(ii)

khว̌s thaạ nòy chăn cà ask way little 1sg FUT

khâwl?'òk

enterlexit

'May I have the way please? I wish to go inlgo out.' 
distinguishes between the "conformation' i.e. Region, and the 'vector' which "comprises the three basic types of arrival, traversal and departure that a Figural schema can execute with respect to the Ground schema" (ibid: 53), the latter notion corresponding to our usage of the term Path. Since in this narrow(er) definition Path is always specified in relation to an explicit or implicit landmark, it can also be said to be based on the object-centered Frame of Reference (FoR).

So how is Path expressed in the three languages under analysis? The

English sentence $I$ went into the room can be most naturally translated as (6) in Swedish and (7) in French.

Jag gick in

1sg go/PAST in/DIR

(i rum-met)

in/ $\mathrm{L}$, $\mathrm{C}$ room-DEF

(7)

Je suis entré

1sg AUX enter/PAST

(dans la pièce)

in DEF room

The contrast between "verb-framing" and "satellite-framing" is here even clearer than in the introductory examples (3) and (4), since in both (6) and (7) there are prepositional phrases expressing the Region in which the Path of motion ends: the INTERIOR of some particular room - and both can also be omitted if this Region can be inferred from the context. But the Path ('vector') itself is lexicalized in Swedish by the verb-particle in - which, note, is distinct from the preposition $i$ - while in French this is done by the main verb entrer 'enter'. What about Thai then? The simplest ${ }^{5}$ way to render this motion event is given in (8).
(8)

chăn khâw *(hôn)

1sg enter room

This construction is most similar to the French (7), since it is the main verb that expresses Path, but is even simpler in that it does not require a preposition. ${ }^{4}$ However, as shown, it is impossible to omit the landmark nominal - unless a deictic verb pay/maa is added, as will be described in the next section. ${ }^{5}$

Though this can be done if the landmark is clearly obvious from the context as in (ii), as pointed out by Kingarn Thepkanjana (p.c.):

The "reverse" motion event - I went out of the room - is rendered likewise in the three languages, as shown in (9), (10) and (11), save that Thai now also requires a preposition, making the similarity with French even greater, leading some analysts such as Weinold (1995) to classify Thai as a V-language.

${ }^{5}$ Though arguably not the most natural one, which would rather be (i):

(i) chăn khâw pay nay hôn lsg enter go in room ${ }^{6}$ Save for the lack of morphological markers for tense and definiteness, it is similar to the non-prototypical English sentence with a Romance-borrowed motion verb I entered the room

${ }^{7}$ Though this can be done if the landmark is clearly obvious from the context as in (ii), as pointed out by Kingarn Thepkanjana (p.c.):

(ii)

khว̌ว thaạ nòy chăn cà
ask way little 1sg FUT khâw \?’̀ok enterlexit

'May' I have the way please? I wish to go inlgo out.' 
(9)

$\begin{array}{ll}\text { Jag } & \text { gick ut } \\ \text { 1sg } & \text { go/PAST out/DIR } \\ \text { (ur } & \text { rum-met) } \\ \text { out/DIR } & \text { room-DEF }\end{array}$

(10)

Je suis sorti

1sg aUX exit/PAST

(de la pièce)

from DEF room

(11)

chăn ?ว̀ok *(càak hộ)

1 sg exit from room

But one need not go far to find differences between Thai and French. Being a serial-verb language, Thai can "stack" two verbs expressing complementary Path notions as in (12). If we define Path to be always related to a landmark (and thus based on an objectcentered FoR) it is difficult to find Thai examples with more than two Path verbs following each other. But if we also consider verbs which express the shape of the trajectory, or what we can call Direction, then we can easily construct a sentence with a series of four verbs, as in (13). As originally observed by Thepkanjana (1986), there is a requirement in this case for Direction verbs such as won ('curve') and yón ('reverse') where the motion is not specified in relation to a landmark to precede the Path verbs proper, making e.g. (14) ungrammatical.

chăn klàp khâw hôn 1sg return enter room 'I went back into the room.'
(13)

chăn won yóon klàp khâw 1 sg curve reverse return enter

hồ

room

'I curved back into the room.'

(14)

*chăn klàp khâw won

1sg return enter curve

yóon hôn

reverse room

This ordering constraint can be reasonably explained in terms of the iconicity of the serial-verb construction: in the represented motion event 'I' first 'curve', then 'reverse' and then 'return into' the room, rather than vice versa.

In sum, from our discussion of Path expression in the three languages, we can conclude that Thai behaves like a V-language, albeit a rather "special" one with its ability to "stack" Path and Direction verbs.

\section{Expression of Deixis (combined with Path)}

While the category Path presupposes an object-centered FoR, as pointed out above, the category Deixis is based in a viewpoint-centered FoR. This latter concept is a generalization of Levinson's (1996, 2003) relative reference frame which is always ternary as in The ball is behind the tree (from the speaker's point of view). On the other hand, our notion of viewpointcentered FoR can also be binary, as in Come here, and thus potentially independent of any landmark.

The separation of Path and Deixis is important for our present analysis since 
it turns out that with respect to the expression of Deixis, all three languages differ! The English sentence He came out of the room, with the Deictic Center (DC) defining the viewpoint positioned "outside the room", can be translated most directly into Swedish using example (15). Here Deixis is introduced by the main verb komma, which replaces the verb ga ('go', 'walk') in (5), otherwise leaving the expression of Path in the satellite $u t$ unchanged.

$\begin{array}{lll}\text { Han } & \text { kom } & \text { ut } \\ 3 \mathrm{sg} / \mathrm{M} & \text { come/PAST } & \text { out/DIR } \\ \text { ur } & & \text { rum-met. } \\ \text { out-of/DIR } & \text { room-DEF }\end{array}$

It turns out that this motion event can not be satisfactorily rendered in French! This is surprising, especiaily since as show $n$ in (16) the verbs venir/aller code for : deictic contrast that is similar to, ever if not identical to, the English pair come/go (Lebaud 1989; Chuquet and David in press).

a.

Il est venu

$3 \mathrm{sg} / \mathrm{M}$ AUX come/PAST

dans la pièce

in DEF room

'He has come inside the room' (DC is inside the room)

b.

Il est allé dans la pièce $3 \mathrm{sg} / \mathrm{M}$ AUX go/PAST in DEF room

'He has gone inside the room' (DC is outside the room)

Note that in (16) neither the verbs nor the preposition dans ('in') express an explicit boundary-crossing. It is pragmatically inferred, rather than semantically coded (Levinson 2003; Zlatev 2003) - much like the use in English sentence glosses using 'inside'. This becomes obvious if we attempt to reverse the direction of motion to the OUTSIDE Region of the room using the same verbs, but changing the preposition: the result is ungrammatical, or at least unacceptable (17).

$$
\begin{aligned}
& \text { a. ??Il est venu de la pièce } \\
& 3 \mathrm{sg} / \mathrm{M} \text { AUX come/PAST from } \\
& \text { DEF room } \\
& \text { 'He has come from the room.' (toward } \\
& \text { DC) }
\end{aligned}
$$

b.

??Il est allé de la pièce

$3 \mathrm{sg} / \mathrm{M}$ AUX $\mathrm{gO} / \mathrm{PAST}$ from DEF

room

'He has gone from the room.' (away from $\mathrm{DC}$ )

\begin{abstract}
${ }^{8}$ In the imperative, this seems to be possible, presumably due to support from the hereand-now context, as shown in (i) using a spatial adverb dehors, (ii) the composite preposition hors de 'out of ' with a landmark nominal and (iii) the spatial deictic ici 'here', and if necessary to be explicit, an extra prepositional phrase.
\end{abstract}

(i)

viens dehors

come out

'Come out here'

(ii)

viens hors de la pièce

come out of the room

'Come out of the room'?

(ii)

viens ici, à l'extérieur de la pièce come here to DEF outside of DEF room

'Come here, to the outside of the room' 
The conclusion must be that French does not allow the combination of a Deictic verb (and in particular venir, which like the English come is the more deictic one of the pair venir/aller) with explicit mention of boundary-crossing (Slobin and Hoiting 1994), at least in the indicative mode. As will be shown below, this also applies to Manner verbs like courir ('run'), making it mandatory to use Path verbs like sortir ('exit') every time there is to be an explicit coding of a boundary transition.

But even when a Path verb is used, it turns out to be impossible to capture the exact meaning of He came out of the room, or the Swedish example (5) in French. As (18) shows, the Path verb cannot be combined with the spatial deictic ici 'here'. The closest one can come to the English and Swedish sentences is the last option, using a nonspatial personal deictic moi 'me'. But while this introduces a viewpointcentered FoR, it does not fully capture the meaning of come and komma, which express movement towards the DC, not necessarily the speaker (Fillmore 1997). Thus I came outside would be untranslatable in French!

Il est sorti

$3 \mathrm{sg} / \mathrm{M}$ AUX exit/PAST

(de la pièce)

from DEF room

*ici / *à ici / en s'avançant vers moi

here / to here / advancing towards me

Turning finally to Thai, we can see that functionally the sentence (19) is much more similar to the Swedish example (15) than the French (18), since both Path and Deixis are expressed in separate simple morphemes in the same clause. However, in Thai they are both verbs, while in Swedish only the first one is. Together with the Deictic verb maa ('come') the Thai sentence is complete, and unlike the case with a "bare" Path verb in (11), the landmark phrase can be omitted. The explanation for this, proposed by Zlatev (2003), was a general principle of spatial semantics: every complete spatial sentence needs to (explicitly) express at least one Frame of Reference, and the supposition that Thai path verbs, unlike Swedish satellites and French verbs, do not contain an explicit expression of the object-centered FoR.

khăw ?ว̀sk maa (càak hôn) 3 sg exit come from room

Another interesting generalization to be made about Thai deictic verbs is that they always appear in final position of the verb series in the (simple) motion event construction, i.e. following any Path verbs, as shown in (20).

chăn klàp khâw pay/maa

1sg return enter go/come nay hôn inside room

'I came back inside into the room.'

If the Deictic verb precedes a Path verb as in (21), that Path verb expresses a second sub-event in a complex MEC which may have a Purposive interpretation, as shown by the English gloss:

(21)

chăn klàp pay/maa

1sg return go/come

khâw (nay) hôn

enter (inside) room

'I came back (in order) to enter the room.' 


\section{Expression of Manner}

Like Path, Manner-of-motion is also a rather ambiguous concept, and can be interpreted either broadly, involving sub-categories such as Body-motion (running), Body-posture (stooping), Vehicle (by car), Speed (in a hurry), Force-dynamics (piercing) Medium (through water) and possibly others. Alternatively, it can involve only the type of (human or non-human) bodily motion that leads to the translocation in a motion event, expressed in verbs such as run, crawl, leap, trot, tiptoe etc. In this section we consider Manner only in the narrow sense, though in a later section, when discussing the possibility of conflating Path and Manner information in a single verb, we will also use the broader notion.

As pointed out by Talmy (1985) and Slobin $(1996,2003)$ it is characteristic for S-languages to have a large number of Manner verbs (both in the narrow and broad sense) in their lexicons, while in $\mathrm{V}$-languages this set is much more restricted. Thus, Swedish has many rather specific Manner verbs like stöta ('barge'), kliva ('stride'), tassa ('tiptoe'), vada ('wade through water'), pulsa ('wade through snow') etc. while French lacks corresponding specific Manner verbs.

Thai is in this respect closer to Swedish than to French - not only does it have the relatively small set of Manner verbs typical for V-languages such as daan ('walk'), wîn ('run'), piin ('climb') etc. but also verbs making rather fine semantic distinctions similar to those in Swedish e.g. kracoon ('leap'), jôy ('tiptoe'), kâaw ('stride'), khajèy ('limp'), luiaj ('creep, for snake-like animals'), luj ('wade'), bù̀ ('rush'), $h \varepsilon^{\prime} \varepsilon$ ('parade'). Thus, the English sentence He strode through the water can be translated with Manner verbs in Swedish (22) and Thai (23), but requires an adverbial phrase in French (24).

(22)

Han vada-de genom

$1 \mathrm{sg} / \mathrm{M}$ wade-PAST through vattn-et.

water-DEF

(23)

khăw dəən kâaw khâam náam

3 sg walk stride cross water

(24)

$\begin{array}{ll}\text { Il a } \quad \text { marché } \\ \text { 3sg/M AUX } & \text { walk/PAST } \\ \text { à grands pas } & \text { dans l'eau } \\ \text { with big steps } & \text { in DEF water }\end{array}$

\section{Combination of Manner, Path} and Deixis

As shown earlier, it is very difficult to combine Path and spatial Deixis in a single clause in a French MEC. The case is the same for Manner and Deixis, unless Manner is expressed in an optional adverbial as in (25). If a Manner verb is used, Deixis can only be expressed using a personal pronoun or a rather heavy prepositional phrase, as in (26).

Il est venu en courant $3 \mathrm{sg} / \mathrm{M}$ AUX come/PAST running

'He has come running' 


$$
\begin{aligned}
& \text { II a couru } \\
& \text { 3sg/M AUX run/PAST } \\
& \text { en s'avançant vers moi } \\
& \text { advancing towards me } \\
& \text { /dans cette direction } \\
& \text { in this way } \\
& \text { 'He ran toward me/in this way.' }
\end{aligned}
$$

It is on the other hand easy to combine a Manner verb and a spatial deictic, as in (27), but the interpretation is not translocative, and thus this is not an instance of a MEC.

$$
\begin{aligned}
& \text { Il a } \quad \text { grimpé ici } \\
& \text { 3sg/M PAST climb/PAST } \\
& \text { here'He climbed here.' }
\end{aligned}
$$

Path and Manner can be also combined, with Path in the main verb and Manner in an adjacent adverbial similar to (25), as explained earlier and shown in (4). Combining the three categories is possible only using the strategies of personal pronoun or directional deixis, in the order Path $>$ Manner $>$ Deixis, as shown in (28). As will be seen below, this contrasts with the mandatory ordering in Thai.

$$
\begin{array}{llll}
\text { Il } & \text { est } & \text { sorti } & \text { en courant } \\
3 \mathrm{sg} / \mathrm{M} & \text { AUX } & \text { exit/PAST } & \text { running }
\end{array}
$$

en s'avançant vers moi advancing towards me

'He ran out this way.'

Swedish has the ability to combine Deixis and Path without relying on adverbials, as was shown already in example (15) which combines a Deictic verb and a Path satellite. However, if Deixis and Manner are to be expressed in the same clause one must be put in an adverbial as in (29) and (30), very much like in English, as shown by the glosses.

$\begin{array}{ll}\text { Han kom } & \text { ut } \\ 3 \mathrm{sg} / \mathrm{M} \text { come/PAST } & \text { out/DIR } \\ \text { springande. } & \\ \text { running } & \\ \text { 'He came out running' } & \end{array}$

$\begin{array}{lll}\text { Han } & \text { sprang } & \text { ut } \\ 3 s g / M & \text { run/PAST } & \text { out/DIR here/ }\end{array}$ hit-åt.

DIR-toward

'He ran out this way.'

In comparison, Thai is the most flexible of the three languages when it comes to the ability to combine different information in the same clause. As shown in the previous three sections, serial verbs allow Thai to combine the expression of the categories Manner, Direction (i.e. "path" that is not related to a landmark), Path and Deixis in a single simple MEC. As already shown, these categories must obey the order Manner-V $>$ Direction-V $>$ Path-V > Deictic-V as in example (31).

khăw dəən yóon khâw maa '(S)he walked back into the house.' (towards the DC)

We would argue that there is no a priori reason to regard only one of the verbs as the main verb and the others as (grammatically) subordinate, and even less so as "satellites". However, this is often disputed, arguably on the basis of an analogy with S-languages like Swedish where only the manner verb is a main verb. This was presumably the basis for Talmy's (1991) analysis of 
Chinese and Lahu as S-languages. Similarly, Sak-Humphry, Indambraya and Starosta (1997) argue that in Thai and Khmer, when a Manner verb leads the serial-verb construction as in (31), the following Path expression(s) are not verbs but "deverbial adverbs".

Zlatev and Yangklang (2004) argued against this, and below we summarize the evidence cited there, with some modifications and corrections.

(a) Any one of the four verbs in (31) can appear alone without making the sentence incomplete; this is not the case with satellites: *John in.

(b) If the "deverbal adverbs" are more grammaticalized than the verbs they derive from, then their semantics should be more "bleached" (Traugott and Dasher 2002). But there is no semantic difference between the "truly verbal" uses of Path expressions as in examples (11-13) where there is no preceding Manner verb, and those in (31) where there is. Some "bleaching" can however be admitted from the Deictic verbs pay/ maa.

(c) If the Path verb occurs as a single verb in the clause, the sentence will nevertheless express a MEC, as in (8). However, if there is only a Manner verb as in (5d), the most neutral interpretation would not be translocative, but one of "self-contained" motion. Hence, the Path verb can not be said to have any "adverbial", modifying function, but is rather the one that truly "frames" the MEC. Together with argument (a), this should lead us to treat the Path verb(s) in (31) as "framing verbs". (d) If only a single Path expression could be added to the Manner verb, one could perhaps suspect that it is being reanalyzed as a verb-particle. But as shown above there can be at least four such verbs: One could, for example, add the verb series from (13) to the manner verb dəən ('walk') to produce ?(32) below. Would it mean that the five expressions, classed as verbs when not following Manner verbs, should be classed as "homonymous deverbal adverbs" when they do follow a Manner verb? Hardly.

dəən won yóon klàp khâw walk circle reverse return enter hồ room

'(Someone) walked in a circular manner back into the house.'

Thus we can conclude that the analogy from S-languages to serial-verb languages is not that good after all. Or rather, as all analogies - it is partial. The disanalogous aspects are those that motivate treating Thai as belonging to a separate language type from e.g. Swedish. One final argument has to do with the scope and focus of negation, with respect to which we wish to compare the three languages in more detail and thus deserves a separate section.

\section{Scope and focus of negation}

One specific way to analyze the semantic contributions of the different expressions in a MEC is by analyzing the scope and focus of VP-negation. It has been noted by e.g. Givón (2001) that the most strongly asserted element in an affirmative clause is also the one that "attract[s] the focus of negation" in a 
negative clause (ibid: 382 ). An optional constituent most often takes on this double role (depending on whether the clause is affirmative or negative) - if there is no contrastive stress to mark some other element as the asserted/ denied information. Thus, in (33), it is the prepositional phrase with a gun that attracts the focus of negation if the sentence is pronounced with neutral intonation.

She didn't shoot him with a gun. (Givón 2001: 381)

In the case of a MEC, the situation seems to be somewhat more complex. To some extent we can consider the landmark nominal phrase "optional", as shown in (6) and (7) for Swedish and French, and in the negative clause in (34a) below for English. But in a neutrally pronounced (34a), the negation can involve both the Landmark (34b) and the Direction (34c). But what negation can not focus on is Manner, showing that in (34a) a "neutral" kind of manner has been presupposed rather than asserted.
a. He didn't go up (the stairs)...
b. ... he went up the ladder.
c. ... he went down the stairs.
d. *...he crawled up the stairs.

But this seems to change with "nonneutral" Manner expressions such as that in (35), showing that it is at least as strongly asserted in an affirmative clause as the Path itself - if not more so: at least to some native speakers, (35b) is preferred to (35c) as a continuation of (35a), if the latter is pronounced as neutrally as possible.
(35)
a. He didn't run into the house...
b. ...he walked into it.
c. ?...he ran out of it.

The situation in Swedish is quite similar to that in English: (36) is a translation of (35) and to the extent that it is at all possible to imagine (36a) being pronounced neutrally, (36b) is likely to be the preferred continuation, showing again that Manner is strongly asserted in affirmative sentences, at least when it in some ways deviates from the "norm".

a.

$\begin{array}{llll}\text { Han } & \text { sprang } & \text { inte } \\ 3 \text { sg/MASC } & \text { run/PAST } & \text { not } \\ \text { in i } & \text { hus-et... } & \\ \text { in/DIR } & \text { in/LOC } & \text { house-DEF } & \end{array}$

b.

...han gick in.

$3 \mathrm{sg} / \mathrm{M}$ walk/PAST in/DIR

c.

?...han sprang $\quad \boldsymbol{u t}$

$3 \mathrm{sg} / \mathrm{M}$ run/PAST out/DIR

ur det.

out-of/DIR it

In French, the focus on Manner is even clearer. We saw repeatedly earlier that when combined with Path, Manner is expressed through an optional adverbial; and in that case it becomes most strongly asserted in an affirmative clause and most strongly negated in a negative one. This is the case even when the Manner of motion is a "normal" one as in (37) below. 


$\begin{array}{lll}\text { a. } & & \\ \text { Il n'est } & \text { pas } \\ \text { 3sg/M NEG/AUX } & \text { NEG } \\ \text { entré } & \text { dans } & \text { la maison } \\ \text { enter/PAST } & \text { in } & \text { DEF house } \\ \text { en marchant } & & \\ \text { walking } & & \end{array}$

'He didn't walk into the room.'

b.

... il est entré

$3 \mathrm{sg} / \mathrm{M}$ AUX enter-PAST

en courant.

running

'He ran in.'

c.

?... il est sorti

$3 \mathrm{sg} / \mathrm{M}$ AUX exit/PAST

en marchant

walking

'He walked out.'

In ' hai, the negative operator for VPneg tion mâydây contains the Manner, Path and Deictic verbs in its scope logically, and Zlatev and Yangklang (2004) suggested this as further evidence for the verbal character of post-Manner verb expressions. In itself, however, this is not sufficient. As shown in (36) and (37), the negative operators inte in Swedish and ne + pas in French include much more than verbs in their scope. What would be necessary is to show that the Path verb is equally much in focus with these other expressions unlike the case with Swedish, and especially with French, where we saw that this was not the case.

The Thai equivalent (without the landmark phrase) to (36) and (37) is presented in (38) below. Both (38b) and (38c) are possible normal continuations to (38a), pronounced with a noncontrastive intonation. This suggests (again) that Manner and Path are expressed "equipollently". This is further supported in (38d), where both are interpreted as being negated in (38a). However, this is not the case for Deixis, which can not be interpreted as the only element negated in (38a), as shown in (38e). For that last clause to be the continuation of the first, the speaker would have to be denying his or her viewpoint - from the "outside" in (38a) and from the "inside" in (38e). But clearly, this is the most weakly asserted and most strongly presupposed aspect of the Thai MEC, and consequently cannot attract negation. This is also seen in (38a) where in negating the Path - from "entering" to "exiting" - the Dectic verb must change as well, thereby allowing the viewpoint to remain unchanged.

a.

khăw mâydây dəən khâw pay...

1sg NEG walk enter go

'(S)he did not walk in (away from DC)...

b. ...khăw wî̉n khâw pay ...(s)he ran in' (away from DC)

c.

... khăw dəən ?ว̀วk maa

... (s)he walked out' (toward DC)

d.

...khăwwîn phàan pay

...(s)he ran by' (away from DC) 
e.

$$
\begin{aligned}
& \ldots \text { *khăw dəən khâw maa } \\
& \ldots \text { (s)he walked in' (toward the } \\
& \text { DC) }
\end{aligned}
$$

This analysis, along with the fact that the Deictic verbs are highly frequent (Zlatev and Yangklang 2004) and semantically general, can lead us to the conclusion that if any Thai expressions are to qualify for the role of "satellites" in MECs, these are the ones. However, this does not hold for the Path verbs, at least not in intransitive MECs.

\section{The boundary-crossing constraint}

Following Aske's (1989) work on Manner verbs in Spanish, Slobin and Hoiting (1994) identified the so-called boundary-crossing constraint, according to which Manner verbs cannot be used to describe situations in which a boundary is crossed. This generalization, supported through both (intuitionbased) grammatical analyses and corpus studies (Slobin 2000, 2003), stresses that V-languages obey this constraint, while S-languages do not. Our two representative languages clearly follow this prediction. The Swedish example (39) uses a Manner verb in a boundarycrossing context, while in French it is impossible to combine a Manner verb with boundary-crossing in a singleclause MEC: (40a) does not have translocative motion, (40b), attempting to combine Manner and Path, is ungrammatical, while (40c) consists of two clauses.
(39)

Han sprang in i hus-et. $3 \mathrm{sg} / \mathrm{M} \mathrm{run} / \mathrm{PAST}$ in/DIR in/LOC house-DEF 'He ran into the room'

$\begin{array}{lll}\text { a. } & \text { a couru } & \text { dans } \\ 3 \mathrm{sg} / \mathrm{M} & \text { AUX run/PAST } & \text { in }\end{array}$ la maison.

DEF house

'He ran inside the house'.

b.

*Il a couru

3sg/MASC run/PAST

en entrant dans la maison entering in DEF house 'He ran entering the house.'

c.

Il a couru pour $3 \mathrm{sg} / \mathrm{MASC}$ run/PAST to entrer dans la maison enter in DEF house 'He ran (in order) to enter the house.'

The only way to express the meaning of run inte or run out of in French is by the now familiar combination of a Path verb and a Manner adverbial as in (41).

a.

Il est entré $3 \mathrm{sg} / \mathrm{M}$ AUX enter/PAST dans la maison en courant in DEF house running 'He ran into the house.'

b.

Il est sorti $3 \mathrm{sg} / \mathrm{M}$ aUX exit/Past de la maison en courant from DEF house running 'He ran out of the house.' 
On the other hand, as demonstrated in (42), Thai does not have any problem whatsoever in using a Manner verb with boundary-crossing - something that directly contradicts any claims to its being a V-language.

$$
\begin{aligned}
& \text { chăn wîn khâw pay nay } \\
& 1 \text { sg run enter go in } \\
& \text { bâan } \\
& \text { house } \\
& \text { 'I ran into the house'. (away from DC) }
\end{aligned}
$$

chă dəən khâam thanǒn khâw 1sg walk cross road enter paj naj sǔan go in park

'I walked across the road (and) into the park.'

\section{Multiple expressions of Path (in a single clause)}

Another difference between S- and Vlanguages, related to but distinct from the boundary-crossing constraint, is the ability to "stack" Path-expressions in the same clause. In V-languages this is generally not possible, and French obeys this restriction. In order to combine two different Path expressions, two different clauses are necessary: This combination can consist of a main clause (44a) and a subordinate clause (44b) or of two conjoined main clauses (44a) and (44c)

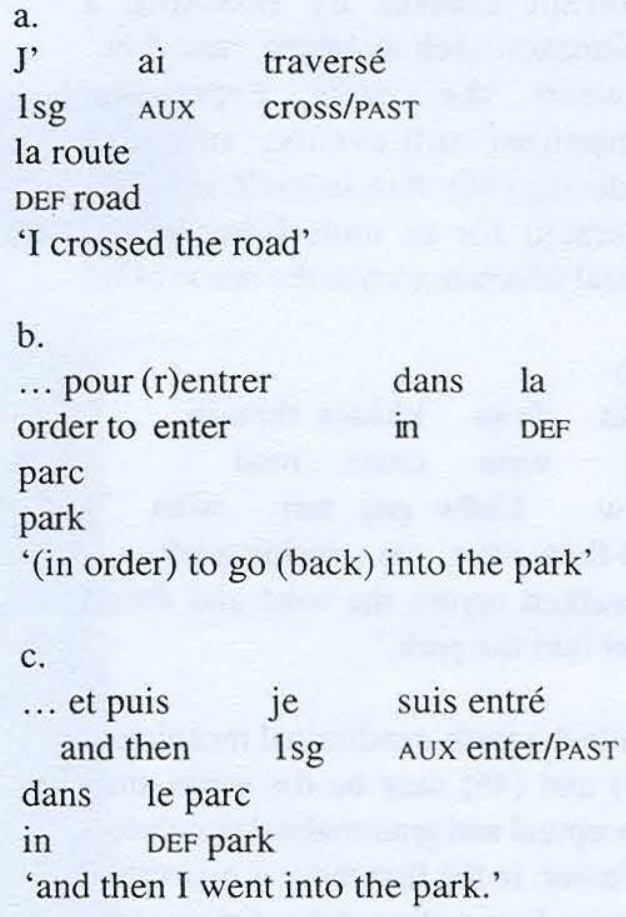

b. $\begin{array}{lll}\ldots \text { pour (r)entrer } & \text { dans } & \text { la } \\ \text { order to enter } & \text { in } & \text { DEF }\end{array}$ parc park '(in order) to go (back) into the park'

c. $\begin{array}{cll}\text {... et puis } & \text { je } & \text { suis entré } \\ \text { and then } & 1 \mathrm{sg} & \text { AUX enter/PAST }\end{array}$ dans le parc in DEF park 'and then I went into the park.'

In Swedish, as is generally the case for $\mathrm{S}$-languages, this is unproblematic, as show $n$ in (45).

Jag gick över gata-n in 1sg walk/PAST over street-DEF i park-en. in/DIR in/LOC park-DEF

'I walked over the road into the park.'

It may be objected that this sentence really consists of two clauses, with a silent conjunction and "elliptic verb", but such claims can be countered. Evidence against such an analysis is not only the single intonational contour, but also the fact that the order of Path expressions in single clauses can be predicted by their temporal iconicity, while this is not the case for separate clauses. 
The same argument can be made for the Thai equivalent (43), which parallels the structure in (45) quite closely. While it is possible to "break up" (43) into different clauses by inserting a conjunction such as lǽæw 'and then' between the parts expressing component sub-events, and thus producing (46), this, in itself, is not an argument for an underlying multiclausal structure such as the one in (43). 9

chăn dəən khâam thanǒn

1sg walk cross road

lécw khâw paj naj sǔan and-then enter go inside park

'I walked across the road and then I went into the park.'

While the truth-conditional meaning of (43) and (46) may be the same, their conceptual and grammatical structure is different: in the first there is no explicit temporal separation and ordering of the sub-events, while in the second there is. Evidence for this is again that (43) is produced as one intonationa! unit (Chafe 1994) while (46) is produced as two. Semantically, the sequentiality between the two sub-events in (43) is implicit, and as observed with respect to Swedish above, the order of the verbs reflects this. In the bi-clausal variant, the temporal order is made explicit through the conjunction lǽw 'and then'. Enfield (2002) has recently argued the same point with respect to

\footnotetext{
${ }^{9}$ Zlatev and Yangklang (2004) made this mistake in defining clauses in Thai, but fortunately this does not mar the major argument presented there: that Thai instant iates a distinct language type.
}

Lao, which in this (and other) aspects is exactly like Thai. Enfield furthermore suggests that unlike multi-clause complex events, most of the single-clause MECs consisting of several sub-events constitute representations of cultural events, which due to frequency and saliency have become schematized. Such an event can, for example, be captured in a single clause in (47), while this would be impossible in not only V-languages like French, but also in S-languages, as reflected in the Swedish gloss.

chăn pay tàlàat stŭt khâaw maa 1 sg go market buy rice come 'I went to the market to buy food'.

\section{Conflation of Manner and Path/Direction: MP verbs}

Zlatev and Yangklang (2004) suggested that apart from the major types of verbs in Thai discussed so far-Manner, Path and Deictic verbs, as well as the Direction verbs such as won 'curve', independent of a landmark - there is another class, combining aspects of Manner and Path, now interpreting these concepts in their broad senses. This class contains verbs of downward motion such as tok 'fall', lon 'fall', lóm 'collapse', com 'sink' and verbs of "force dynamic" motion through a barrier, with degrees of suddenness and resistance such as phloo 'pop-out', thalú 'pierce', thîm 'puncture'.

Such MP verbs in Thai appear to form a separate category syntactically as well as semantically and their position in a MEC is where it would be predicted on semantic grounds: following the Manner verb, but preceding the Path verb(s) as shown in (48a). Violations of this 
constraint, e.g. (48b) and (48c), result in ungrammaticality.

a.

khăw dəən phlòo ?ว̀ok pay 3sg walk pop-outexit go

'(S)he walked out suddenly.'

b.

* khăw phlòo dəən ?ว̀sk pay

c.

* khăw dəən ?ว̀วk phlòo pay

It is also possible to combine more than one MP verbs, as in (49).

khăw tòk thalú khâw maa

3sg fall piece enter come ' $(\mathrm{S})$ he fell through (something) to the inside (of something).'

It seems to be more difficult to combine MP verbs and the (landmarkindependent) Direction verbs such as those discussed briefly in connection with Path verbs above. But this difficulty is not absolute, and is possible, at least in colloquial style (50a), while the reverse order of Direction and MP verbs is ungrammatical, (50b).

a.

khăw won phlò ?j̀ok maa 3sg curve pop-up exit come '(S)he curved and popped in.'

b.

* chăn phlòo won ?j̀ok maa

Thus we can establish the order of verbs within a (single clause) intransitive MEC in Thai, shown in (51).

\section{(51) Manner-V > Direction-V > MP-V $>$ Path-V > Deictic-V}

Turning to Swedish and French, we can only find a few verbs that appear to conflate Manner (Medium) with downward motion:

$$
\begin{aligned}
& \text { falla 'fall', ramla 'fall over', } \\
& \text { sjunka 'sink, move down } \\
& \text { through water'... (Sw) } \\
& \text { tomber 'fall (over)', couler } \\
& \text { 'sink', sombrer 'sink (for a } \\
& \text { boat)' ... (Fr) }
\end{aligned}
$$

Despite their semantic near-equivalence these verbs are treated differently grammatically in the two languages! In Swedish, they come under the same paradigm as Manner verbs, and (usually) combine with the Path satellite ner 'down', as shown in (52). In French, however, they are treated as Path verbs expressing translocation, and combining with an optional manner expression as in (53).

Han ramla-de ner
3sg/m fall-pAST down
(på mark-en)
on ground-DEF
'He fell down on the ground.'

Il est tombé (en courant). $3 \mathrm{sg} / \mathrm{M}$ AUX fall/PAST running

'He fell while running.'

Thus, with respect to verbs that conflate Path and (aspects of) Manner, all three languages differ. 


\section{Expression of Cause-of-Motion}

In our comparison of Swedish, French and Thai MECs we have thus far only considered intransitive motion, where the trajector is the grammatical subject. Before concluding, let us turn to the second major type of MECs: transitive ones, where an agent (or actor) usually coded by the grammatical subject, causes the motion of the trajectory, usually the direct object, along some particular trajectory.

Since most of the characteristics of transitive and intransitive MECs are the same, and for the sake of brevity, we will consider only MECs with an objectcentered frame of reference and including boundary-crossing, as in the English sentence I threw the ball out of the room, where there turns out to be some differences compared to what we have already observed.

A common characteristic of all transitive MECs is that the main verb expresses the Cause-of-Motion (CoM). In Swedish, CoM verbs such as kasta ('throw') and putta ('push') behave like - and take the place of - Manner verbs, as was suggested in Talmy's (1985) original analysis of verbal lexicalization patterns. As shown in (54), the CoM verbs can participate in the expression of translocative motion across a boundary, as was also the case with Manner verbs.

$\begin{array}{lll}\text { Jag } & \text { kasta-de } & \text { boll-en } \\ \text { lsg } & \text { throw-PAST } & \text { ball-DEF } \\ \text { ut } & \text { ur } & \text { rum-met }\end{array}$

out/DIR out-of/DIR room-DEF 'I threw the ball out of the room.'
The French translation of example (54) is given in (55). It can be observed that the two are structurally very similar. This was not the case with Manner verbs in intransitive MECs, where due to the boundary-crossing constraint, a Manner verb could not be used in French. The conclusion appears to be that $\mathrm{CoM}$ verbs are different from Manner verbs in French in allowing boundary-crossing.

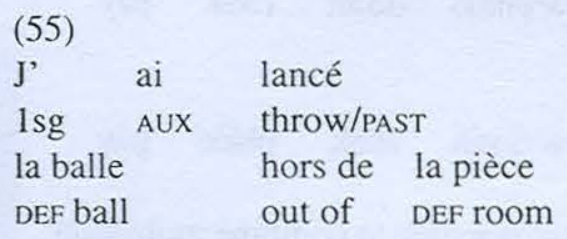

In Thai, common CoM verbs are ?aw ('take'), yïp ('pick up'), sày ('insert'), phaa ('take along'), thòt ('take off'), yók ('lift') and phlàk ('push'). The translation of (54-55) could be given as (56), again with a serial-verb construction. However, unlike sentences expressing intransitive motion, it is easier to see the CoM verb yoon ('throw') as the main verb of the clause, determining the subject (Matsumoto 2003). This can also be demonstrated by applying the focus-of-negation test, as shown in (57).

$\begin{array}{lll}\text { khăw yoon lûk } & & \\ \text { (s)he throw ball } & \text { Pòok } \\ \text { càak hộ } & & \text { exit } \\ \text { from room } & & \end{array}$

'(S)he threw the ball out of the room.'

a.

$\begin{array}{llll}\text { khăw mâydây } & \text { yoon } & \\ \text { (s)he neg } & \text { throw } & \\ \text { lûukbon } & \text { ?òsk } & \text { càak hôn } \\ \text { ball } & \text { exit } & \text { from room }\end{array}$

'(S)he didn't throw the ball out of the room...' 
b.

... khăw tè man 2j̀ok maa

(s)he kick it exit come

'... (s)he kicked it out.'

c.

?? ... khăw yoon man khâw pay

'... (s)he threw it in.'

Unlike in Swedish and French, CoM verbs in Thai can also combine with Manner verbs, as in (58).

$\begin{array}{lll}\text { khăw } & \text { phaa } & \text { lûuk dəən } \\ 3 \text { sg } & \text { take-along } & \text { child walk } \\ \text { Pòวk } & \text { pay } & \\ \text { exit } & \text { go } & \end{array}$

'(S)he took his/her child out walking away.'

On the other hand, it is (nearly) impossible to combine CoM verbs with the "force dynamic" sub-category of MP verbs in a single clause, as seen in (59). The reason appears to be that these verbs imply, at least pragmatically, agency on the part of the trajector and this is lacking when the trajector is the direct object of a transitive CoM verb. This interpretation is supported by the fact that when the MP verb does not imply agency, as is the case with tòk 'fall', combination with a CoM verb is indeed possible, as in (60).

(59)

$\begin{array}{lll}\text { *l??khăw } & \text { yoon lûkbon } \\ \text { 3sg } & \text { throw ball } \\ \text { phlòo } & \text { ?ว̀̀ } & \text { pay } \\ \text { pop-out } & \text { exit } & \text { go'(S)he }\end{array}$

threw the boll popping out.'
(60)

khăw phlàk dèk tòk

3sg push child fall

lon pay

go-down go

'(S)he pushed the child down.'

In sum, with respect to their role in motion event constructions CoM verbs need to be considered a separate syntactic and semantic category in Thai and, at least to a degree, in French as well, due to the fact that they allow boundary-crossing, unlike Manner verbs. In Swedish, on the other hand, apart from the predictable properties related to causation, their properties are similar to those of the Manner verbs in intransitive MECs.

\section{Conclusions}

In this article, we have compared Swedish, French and Thai motion event constructions (MECs) with respect to a number of syntactico-semantic features, the goal being to establish whether Thai mostly resembles French (a Vlanguage), Swedish (an S-language), or both and (thus) neither. Table 1 summarizes the results of the comparison. 
Table 1. Comparison between a number of grammatical (i.e. syntactic and semantic) characteristics of French (V-language), Swedish (S-languages) and Thai ("Equipollent"?).

\begin{tabular}{|l|l|l|l|c|c|}
\hline Characteristic & French (Fr) & Swedish (Sw) & Thai & $\begin{array}{l}\text { Thai } \approx \text { Thai } \approx \\
\text { Fr }\end{array}$ \\
\hline Sw
\end{tabular}

We can first observe that Thai resembles French to a limited degree: both languages use Path verbs, especially for boundary-crossing (BC) situations. Also, they both have Deictic verbs, but so does Swedish, which on the whole appears to be a near-universal property that can not help us determine the typological category of Thai. Finally, both Thai and French treat CoM verbs differently from Manner verbs, though also differently from each other: in Thai the CoM and Manner verbs can be combined, but not in French.
There seems to be more similarities between Thai and Swedish: they both use many detailed Manner verbs, also in boundary-crossing conditions. Similarly, both languages allow the combination of several Path expressions, with or without landmark arguments, in the same clause.

But on closer analysis, especially in considering how the different semantic categories Path, Manner, Deixis, Direction and Cause are combined in a motion event construction, it has been shown that Thai differs from both French and Swedish, with respect to the following characteristics from Table 1: 
(d) The combination of Deixis and Path with boundarycrossing was most cumbersome in French, requiring a heavy Deictic PP such as dans cette direction ('in this way'). In Swedish the preferred way to express this is through a Deictic verb and a Path satellite komma ut ('come out'). Thai is like French in using a Path verb, but different from both in also using a Deictic verb. On the other hand, since this last verb seems to be undergoing grammaticalization, the similarity to Swedish can be said to be on the increase.

(e) In combining Deixis and Manner in MEC, French treats the Deictic verb like a Path rerb, adding Manner, usually hrough an optional adverbial. The Swedish pattern was rather the opposite, with a Manner verb and a Deictic adverb. Thai resembles Swedish in using a Manner verb, but differs in following it with a Deictic verb/ satellite - though admittedly the similarity to Swedish is clearer.

(f) In combining all three categories though, Thai clearly differs from both French and Swedish in using three verbs, always in the order Manner-V $>$ Path-V > Deictic-V, where only the last shows some symptoms of deverbalization.

(g) The "focus of negation" test showed that Path and Manner were equally focal in Thai, while Manner seemed to attract negation more in both French and Swedish. According to the principle "most-strongly-negated $=$ most-strongly affirmed" this would imply that Manner and Path are more equally affirmed in Thai indicative clauses than in the other two languages, confirming their "equipollent" (Slobin 2004) status.

(j) Finally, Thai has a more developed paradigm of verbs conflating Manner and Path/ Direction than either French or Swedish, and treats these differently from the "pure" Manner and Path verbs grammatically, unlike French which treats verbs like tomber ('fall') like its Path verbs, while Swedish treats such verbs (e.g. ramlar) as its major pattern, the Manner verbs.

As pointed out in the introduction, it has been difficult to place serial-verb languages such as Thai within the binary typology of verb-framed languages such as French, and satellite-framed languages such a Swedish. The analyses presented in this article, and the differences summarized above confirm this difficulty, and show quite specifically why languages such as Thai do not fit into the binary typology. Thai resembles French in some characteristics, Swedish in others, but also clearly differs from both. This also makes it impossible to regard Thai as being on a "cline" between S-language and V-languages, as suggested by Slobin and Hoiting (1994): There is simply no consistent metric according to which Thai and languages like it can be positioned "between" S-languages and V-languages. Thus, the argument for 
assigning serial-verb languages to a third type, presented by Essegbey and Ameka (in press), Zlatev and Yangklang (2004) and Slobin (2004) has been supported.

Given the fact that the typology of Slanguages and V-languages has been immensely productive for studies in language typology, "rhetorical style" and a weak type of Whorfian effect shown in "thinking for speaking" and language specific gesture (Talmy 1985 , 2000a, 2000b; Slobin 1996, 1997, 2000; McNeil 2000; Strömquist and Verhoeven 2004), the existence of such a third "equipollent" type raises many new questions:

Which languages can be said to belong to such a class?

What kind of "rhetorical style" do they have?

Do they affect "thinking for speaking" differently?

Do they have iype-specific gesture patterns?

The goals of our future research will be to address these questions by continuing our comparative work with Swedish, French and Thai in the domains of spontaneously produced discourse, spatial cognition and gesture studies.

\section{Acknowledgments}

The authors wish to thank Prof. Pranee Kullavanijaya for her kind invitation to submit a paper to Manusya, Assoc. Prof. Kingkarn Thepkanjana for encouragement and critical comments, as well as an anonymous reviewer with expertise in Thai Linguistics. Furthermore we wish to thank Ingrid Nilsson for comments on the Swedish data, as well as for a number of stylistic corrections to the text. Finally, the first author needs to acknowledge once again the Swedish Foundation for International Cooperation in Research Higher Education-STINT for sponsorship, and the Department of Linguistics and the Centre for Research in Speech and Language Processing-CRSLP and its director Asst. Prof. Sudaporn Luksaneeyanawin for their hospitality during his post-doctoral fellowship.

\section{References}

Bisang, W. (1995). Verb serialization and coverbs - difference and similarities. In M. Haspelmath and E. Konig (eds.) Adverbial Participle, Gerunds. Berlin: Mouton de Gruyter.

Chafe, W. (1994). Discourse, consciousness and time: The flow and displacement of consciousness in speech and writing. Chicago: Chicago University Press.

Chuquet, H. and C. David. (in press). Come: Point de vue et perception dans le récit. In: Chuquet, J. (ed). Verbes de parole, pensée, perception : études syntaxiques et sémantiques. Presses Universitaires de Rennes.

Croft, W. (2001). Radical Construction Grammar. Oxford: Oxford University Press.

Durie, M. (1997). Grammatical structures in verb serialization. In: A. Alsina, J. Bresnan, and P. Sells (eds). Complex Predicates. Stanford: Standford University Press.

Enfield, N. (2002). Cultural logic and syntactic productivity: Associated posture constructions in Lao. In N.J. Enfield (ed.) Ethnosyntax: Explorations in culture and grammar. Oxford: Oxford University Press. 
Essegbey, J. and F. Ameka. (in press). Serializing languages: Satellite-framed, Verb-framed or neither? Proceedings of the $32^{\text {nd }}$ Annual Conference on African Linguistics, University of California, Berkeley.

Fillmore, C. (1997). Lectures in Deixis. Cambridge: CUP

Givón, T. (2001). Syntax. Amsterdam: Benjamins.

Goldberg, A. (1995). Constructions. Chicago: Chicago University Press.

Heine, B., U. Claudi and F. Hünnemeyer. (1991). Grammaticalization: A Conceptual Framework. Chicago: University of Chicago Press.

Jackendoff, R. (1990). Semantic Structures. Cambridge, Mass.: MIT Press.

Khalifa, J.-C. (2001). Linguistique et traduction: le cas des verbes de déplacement. Sigma-Anglophonia ${ }^{\circ}$ 10. Toulouse: Presses Universitaires du Mirail.

Matsumoto, Y. (2003) Causative verbs of notion and typology of motion events. 'aper presented at the 8th International nternational Cognitive Linguistics Conference, July 20-25, Logroño Spain.

Langacker, R. (1987). Foundations of Cognitive Grammar I: Theoretical Prerequisites. Stanford University Press.

Lebaud, D. (1989). Veni, vidi... vici ? Elements d'analyse en vue d'une caractérisation générale du marqueur venir. In J.J. Franckel (ed.) La notion de prédicat. Paris 7, ERA 642.

Levinson, S. (1996). Frames of reference and Molyneux's question: Crosslinguistic evidence. In P. Bloom, M. Peterson, L. Nadel and M.Garret (eds.), Language and Space. Cambridge, Mass.: MIT Press.

Levinson, S. (2003). Space in Language and Cognition: Explorations in Cognitive Diversity. Cambridge: Cambridge University Press.
Pedersen, E., Danziger, E., Wilkins, D., Levinson, S., Kita, S. and G. Sneft (1998). Semantic typology and spatial conceptualization, Language, Vol. 74, Number 3, pp. 557-589.

Sak-Humphry, C., K. Indambraya and S. Starosta (1997). Flying 'in' and 'out' in Khmer and Thai. In A.S. Abarmson (ed.) South Asian Linguistics Studies in Honour of Vichin Panupong. Bangkok: Chulalongkorn University Press.

Senft, G. (2001). What do we really know about serial verbs constructions in Austronesian and Papuan Languages? Paper presented at The Third European Meeting on Oceanic Linguistics, Paris, March 9-10, 2001.

Slobin, D. (1996). Two ways to travel: Verbs of motion in English and Spanish. In M. Shibatani and S. Thompson (eds.), Grammatical Constructions: Their Form and Meaning. Oxford: Oxford University Press.

Slobin, D. (1997). Mind, code and text. In J. Bybee, J. Haiman and S.A.Thompson (eds.), Essays on Language Function and Language Type. Dedicated to T. Givon. John Benjamins.

Slobin, D. (2000). Verbalized events, A dynamic approach to linguistics relativity and determinism. In S. Niemeier and R. Dirven (eds.) Evidence for Linguistic Relativity, Amsterdam: John Benjamins. perspectives. Mahawah, NL: Lawrance Erlboum.

Slobin, D. (2004). The many ways to search for the frog: Linguistic typology and the expression of motion events. In Strömqvist and Verhoeven (2004).

Slobin, D. and N. Hoiting (1994). Reference to movement in spoken and signed languages. Proceedings of the $20^{\text {th }}$ Annual meeting of the Berkeley Linguistics Society.

Stahlke, H. (1970) Serial verb. Studies in African Linguistics 1, pp. 60-99.

Strömqvist, S and L. Verhoeven. (2004). eds., Relating Events in Narrative: Crosslinguistic and Cross-contextual Perspectives, Mahwath, N.J.: Earlbaum. 
Talmy, L. (1983). How language structures space. In: H. Pick \& L. Acredolo (eds.), Spatial orientation: Theory, Research, and Application 225-282. New York: Plenum Press.

Talmy, L. (1985). Lexicalization patterns: semantic structure in lexical forms. In T. Shopen (ed.) Language Typology and Syntactic Description, Vol. 3, Grammatical Categories and the Lexicon. Cambridge: Cambridge University Press.

Talmy, L. (1991). Path to realization: A typology of event conflation. Proceedings of the $17^{\text {th }}$ Annual Meeting of the Berkeley Linguistics Society.

Talmy, L. (2000a). Toward a Cognitive Semantics, Vol. 1 Cambridge, Mass.: MIT Press.

Talmy, L. (2000b). Toward a Cognitive Semantics, Vol. 2 Cambridge, Mass.: MIT Press.

Thepkanjana, K. (1986). Serial verb construction in Thai. Unpublished $\mathrm{Ph}$. D. Dissertation, University f Michigan.

Traugott, E and R. Dasher (2002). Regularity in Semantic Change. Cambridge: CUP

Wienold, G. (1995). Lexical and conceptual structures in expression for movement and space. In U. Egli, P. Pause, C. Schwarze, A. Stechow and G. Wienold (eds.) Lexical knowledge in the organization of language. Amsterdam: Benjamins Press.

Zlatev, J. (2003). Holistic spatial semantics of Thai. In E. Casad and G. Palmer (eds.) Cognitive Linguistics and NonIndo-European Languages. Berlin: Mouton de Gruyter.

Zlatev, J. (in press). Spatial semantics. In: D. Geeraerts and $\mathrm{H}$. Cuyckens (eds.) Handbook in Cognitive Linguistics. Amsterdam: Benjamins.

Zlatev, J. and P. Yangklang (2004) A Third Way to Travel: The Place of Thai in Motion Event Typology. In S. Strömqvist and L. Verhoeven (2004).

Zlatev, J. (1997). Situated Embodiment: Studies in the Emergence of Spatial Meaning. Stockholm: Gotab. 